\title{
Antidepressant induced excessive yawning and indifference
}

\author{
Bocejos excessivos e indiferença induzidos por antidepressivos \\ Bruno Palazzo Nazarr', João Hiluy², Paulo Mattos 3
}

\section{Keywords}

Adverse effects,

antidepressive agents,

apathy, serotonin uptake inhibitors, yawning.

\begin{abstract}
Introduction: Antidepressant induced excessive yawning has been described as a possible side effect of pharmacotherapy. A syndrome of indifference has also been described as another possible side effect. The frequency of those phenomena and their physiopathology are unknown. They are both considered benign and reversible after antidepressant discontinuation but severe cases with complications as temporomandibular lesions, have been described. Methods: We report two unprecedented cases in which excessive yawning and indifference occurred simultaneously as side effects of antidepressant therapy, discussing possible physiopathological mechanisms for this co-occurrence. Case 1: A male patient presented excessive yawning (approximately 80/day) and apathy after venlafaxine XR treatment. Symptoms reduced after a switch to escitalopram, with a reduction to 50 yawns/day. Case 2: A female patient presented excessive yawning (approximately 25/day) and inability to react to environmental stressors with desvenlafaxine. Conclusion: Induction of indifference and excessive yawning may be modulated by serotonergic and noradrenergic mechanisms. One proposal to unify these side effects would be enhancement of serotonin in midbrain, especially paraventricular and raphe nucleus.
\end{abstract}

\section{RESUMO}

Introdução: Alguns relatos de caso descrevem pacientes com bocejos excessivos induzidos por antidepressivos. Também é relatada a capacidade dos antidepressivos induzirem uma síndrome de indiferença. A frequência desses efeitos colaterais é desconhecida, assim como seus mecanismos fisiopatológicos. Ambos os efeitos são considerados benignos e costumam ser reversíveis após a suspensão dos antidepressivos, porém há relatos de casos graves com a ocorrência de luxação temporomandibular devida aos bocejos excessivos induzidos por antidepressivos. Métodos: Relatamos dois casos inéditos de pacientes, apresentando esses efeitos colaterais de forma concomitante, discutindo os possíveis mecanismos fisiopatológicos e explicando essa coocorrência. Caso 1: O paciente apresentou bocejos excessivos e apatia com o uso de venlafaxina XR (cerca de 80 bocejos por dia) e, após a troca para escitalopram por conta desse efeito, teve redução para cerca de 50 bocejos por dia. Também relatava sentimento de lentidão e apatia com ambas as medicações. Caso 2: A paciente apresentou bocejos excessivos (cerca de 25 por dia) e declínio na responsividade emocional a estímulos

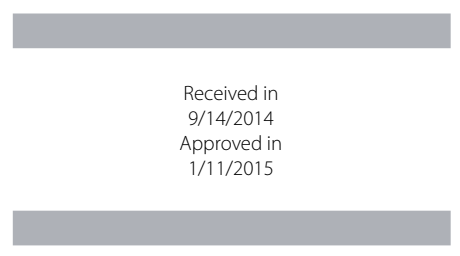

DOI: $10.1590 / 0047-2085000000060$

\footnotetext{
1 Federal University of Rio de Janeiro - Institute of Psychiatry (UFRJ-IPUB), Post Graduate Program of Psychiatry and Mental Health (PROPSAM).

2 UFRJ-IPUB, Psychiatry Residency Program.

3 IPUB-UFRJ. D'Or Institute of Research and Education (IDOR).
}

Address for correspondence: Bruno Palazzo Nazar

Rua Visconde de Pirajá, 547, sala 610, Ipanema

22410-900 - Rio de Janeiro, RJ, Brazil

E-mail:bruno.nazar@ufrj.br 


\section{Palavras-chave}

Efeitos colaterais, antidepressivos, apatia, inibidores de captação de serotonina, bocejo. ambientais, associado à incapacidade de chorar com o uso de desvenlafaxina. Conclusão: A indução de indiferença e de bocejos excessivos parece ser modulada por mecanismos serotonérgicos e noradrenérgicos. Uma proposta que poderia unificar esses efeitos é pelo aumento serotoninérgico no mesencéfalo, especialmente nos núcleos paraventriculares hipotalâmicos e da rafe.

\section{INTRODUCTION}

Yawning is a common behavior in humans and is considered to have different functions, ranging from modulation of brain thermoregulatory changes to being an emotional manifestation of tiredness or boredom'. Salvos of yawning can be an expression of diseases when induced by intracranial hypertension, epilepsy, migraine or dyspepsia². Excessive yawning is mainly associated to sleep deprivation but can also be drug-induced.

Previous reports describe antidepressant induced excessive yawning with imipramine, desipramine, clomipramine, fluoxetine, sertraline, duloxetine and venlafaxine XR. Case reports presented patients of both genres, with diverse diagnoses (bulimia nervosa, major and minor depressive disorder, panic disorder and anxiety disorder not otherwise specified) $)^{3,4}$. It is usually benign but leads to personal and social distress. Antidepressant change or discontinuation leads to yawning resolution within days for most cases, but temporomandibular lesions secondary to excessive yawning have already been reported ${ }^{5}$.

SSRIs can induce a syndrome of indifference that can manifest either as apathy, an emotional blunting with inability to cry or even as an inability to worry and react to environmental stressors ${ }^{6}$. In some patients, all those manifestations can be present at the same time. This syndrome has also been reported in patients of both genres, with many diagnoses [major depressive disorder (MDD), social phobia, obsessive-compulsive disorder, and panic disorder $]^{6,7}$.

We present here two case reports of antidepressant induced excessive yawning associated with a syndrome of indifference. To our knowledge, this is the first case series describing two cases where both yawning and indifference occurred simultaneously.

\section{CASE REPORT 1}

The patient was a 52-year-old male, chief executive officer of a business company, which initiated psychiatric treatment for major depressive disorder. His symptoms had begun three months before medical evaluation. He was started on venlafaxine XR $75 \mathrm{mg} /$ day and showed partial remission of depressive symptoms after one month. The patient stated that after one week of Venlafaxine XR he perceived daily excessive yawning, having up to approximately five yawns/ hour (about 80 yawns/day) and denied experiencing somnolence or sedation. The yawning occurred during business negotiations, social gatherings and conversations with close relatives, which brought professional and marital distress. Yawning was not more frequent in any particular time of day. The patient also developed little motivation for daily activities, which began after three weeks of medication. The patient did not present other side effects. After a follow up consultation, venlafaxine was discontinued and the side effects resolved within four days. Shortly after antidepressant discontinuation, depressive symptoms recurred and a new antidepressant trial with escitalopram 10/day was initiated. After one week of escitalopram, he exhibited recurrence of yawning episodes, approximately 3/hour (about 50/day), and after two weeks, started feeling "slow and unresponsi$v e^{\prime \prime}$, and discontinued the medication on his own, presenting resolution of yawning and indifference within days. Finally, he began bupropion XL $150 \mathrm{mg} /$ day and showed resolution of depressive symptoms without any side effects.

\section{CASE REPORT 2}

A 49-year-old woman, presenting with minor depressive disorder and binge eating disorder (BED), was started on desvenlafaxine, titraded up to $100 \mathrm{mg} /$ day. After two weeks, she started experiencing excessive yawning, approximately 2/hour (25 yawns/day). She also presented stomach pain for the first two weeks of treatment. At a one-month follow up she referred being nervous because of an "emotional numbness". She reported a decrease in emotional responsiveness to environmental stimuli and felt she wasn't able to cry, as sorrow was "locked up inside her". She complained that she had to make too much effort to complete daily tasks and felt slow. This emotional hypoesthesia was more distressing than her yawning. Her depressive symptoms have remitted and binge eating had already decreased significantly. Afterwards, under the suspicion these symptoms could be induced by the antidepressant, she didn't take it for one week and then initiated treatment again, with recurrence of symptoms along another month. She had her medication discontinued with complete resolution of side effects after few days and was started on topiramate $50 \mathrm{mg} /$ day with binge remission. 


\section{DISCUSSION}

Two patients experiencing excessive yawning and indifference induced by antidepressants were presented. Excessive yawning in these two cases followed a typical pattern presented on previous reports: absence of sedation; absence of sleep disorder; regular yawning frequency throughout the day; and social distress. The indifference syndrome also followed a pattern with previously described features consisting of: apathy remains stable and continuous for weeks; patient is aware of emotional restraint and is also distressed by this; diminished spontaneity in actions and speech. Resolution of both yawning and indifference after antidepressant discontinuation, and recurrence after reinitiating the medication strengthens the possibility of their drug induced nature. Previous reports suggested venlafaxine XR could induce excessive yawning ${ }^{3}$ but there are no reports of such side effect in association with indifference, induced by desvenlafaxine or in a patient diagnosed with BED.

Given the distress provoked by yawning and indifference in the patients described in this article, they presented questions regarding side effects directly to their physician. Previous literature reports that distress and impairment with such phenomena may vary and that patients may report such side effects only upon active investigation by the examiner. As such, it is possible that excessive yawning and indifference may occur more frequently and are underdiagnosed.

Three different antidepressants that share serotonergic effects were associated with yawning in the reported patients. Serotonin augmentation has been associated with yawning induction both in clinical and experimental settings. Although there is conflicting evidence regarding serotonin manipulation and yawning in animals, their neurotransmission circuitry may not be similar to what is found in humans. Yawning is a behavioral manifestation in drug experiments with animals and is considered as an outcome measure for central nervous system action. Serotonin augmentation increases yawning in cats and reduces it in rats. Noradrenalin and dopamine increases yawning in rats 8 . In addition, human yawning regulation, especially in the paraventricular nucleus of the hypothalamus, derives from a complex chemical cascade with an imbalance still poorly understood ${ }^{2}$. Also, desvenlafaxine can inhibit noradrenaline reuptake, which is another possible mechanism for this side effect.

The occurrence of apathy and emotional blunting, respectively, as a behavioral and an emotional manifestation of an indifference syndrome ${ }^{7}$, encompasses different aspects of the same underlying process. Antidepressant induced-indifference has an unknown etiology. Two proposals to explain this side effect are: (a) dopaminergic reduction in basal ganglia secondary to serotonin augmentation in raphe nucleus; (b) frontal lobe dysfunction induced by serotonin increases.
The occurrence of both excessive yawning and indifference may be the result of serotonergic increases in the midbrain, especially, the raphe nucleus and the hypothalamic paraventricular nucleus $5^{6,7}$. Also, it is possible that patients may experience the induction of indifference as boredom and activate yawning as a behavioral manifestation expressing this emotional state.

Depression can yield excessive yawning and indifference by itself misleading clinicians to evaluate them as manifestations of depression instead of attributing those as possible side effects of pharmacotherapy ${ }^{2,9}$. Thus, antidepressant increases could potentially lead to worsening of yawning and indifference. It could also be a mistake to ask patients to maintain a serotonergic antidepressant and disregard those side effects as being "minor", since they could lead to social distress and eventually treatment discontinuation. The switch to a non-serotonergic antidepressant may be a possible strategy to resolve those symptoms if the patient needs to maintain antidepressant therapy. Finally, in patients with a previous history of multiple episodes of yawning and/ or indifference with different antidepressants, it should be discussed whether mild or moderate symptoms would be better addressed by a different non-pharmacological treatment plan, as psychotherapy. This case series suggest the need for more data regarding those side effects and their co-occurrence in patients treated with antidepressants.

\section{INDIVIDUAL CONTRIBUTIONS}

Bruno Palazzo Nazar - Patient evaluation and treatment; bibliographic review of data; manuscript preparation.

João Hiluy - Patient evaluation and treatment; bibliographic review of data; manuscript preparation.

Paulo Mattos - Bibliographic review of data; manuscript preparation.

\section{CONFLICTS OF INTEREST}

Bruno Palazzo Nazar and João Hiluy doesn't state significant contributions and are not a speakers and did not perform research to any pharmaceutical company.

Paulo Mattos has been funded by Novartis and Shire Pharmaceuticals, and has received compensation as a member of the scientific advisory board by Novartis, Shire and Janssen-Cilag Pharmaceuticals. Has also received compensation as a speaker from Novartis, Shire and Janssen-Cilag.

\section{REFERENCES}

1. Gupta S, Mittal S. Yawning and its physiological significance. Int J Appl Basic Med Res. 2013;3(1):11-5. 
2. Walusinski 0. Yawning in diseases. Eur Neurol. 2009;62(3):180-7.

3. Patatanian E, Williams NT. Drug-induced yawning: a review. Ann Pharmacother 2011:45(10):1297-301.

4. Roncero C, Mezzatesta-Gava M, Grau-López L, Daigre C. Yawning as a dose-dependent side effect of treatment with escitalopram. Neurologia. 2012;28(9):589-90.

5. Pae CU, Kim JJ, Lee CU, Lee SJ, Lee C, Paik IH. Injured temporomandibular joint associated with fluoxetine-monotherapy-induced repeated yawning. Gen Hosp Psychiatry. 2003;25(3):217-8.
6. Figueira I, Marques C, Fontenelle LF, Nardi AE, Versiani M. Hipoestesia emocional induzida pelos inibidores da recaptação da serotonina (IRS): efeito antipreocupação, apatia e incapacidade de chorar. J Bras Psiquiatr. 1998;47(9):469-76.

7. Sansone RA, Sansone LA. SSRI-induced indifference. Psychiatry (Edgmont). 2010;7(10):14-8.

8. Furukawa T. Yawning behavior for preclinical drug evaluation. Methods Find Exp Clin Pharmacol. 1996;18(2):141-55.

9. Beale MD, Murphree TM. Excessive yawning and SSRI therapy. Int J Neuropsychopharmacol. 2000;3(3):275-6. 